\title{
Study on Sports and Social Responsibility Training for College Students
}

\author{
Yiqi SONG
}

Department of Physical Education, North China Institute of Science and Technology, hebei, china

Xiangbin MU

North China Institute of Science and Technology, hebei, china

\begin{abstract}
Sports with its own unique attributes play an important role in social responsibility training for college students. Physical fitness is conducive to the formation of a healthy sense of responsibility among college students; sports competition is conducive for students to developing awareness of rules and laws; teamwork required in sports will help them develop team spirit; confrontation in sports help students develop competition awareness.
\end{abstract}

KEYWORD: Sports; College Students; Social Responsibility

In July 2010, the new version of Long-term Education Reform and Development Plan was released, which clearly states: "In school education, we must adhere to moral education first and integrate socialist core values into the entire national education. The state defines moral education as a strategic issue in national education, from which we can see the importance of moral education in China. With the Chinese dream proposed, strengthening the social responsibility of college students and developing their eagerness to realize national revival are of great significance in current moral education in colleges and universities.

\section{HEALTH IS THE BASIC FOUNDATION OF SOCIAL RESPONSIBILITY}

With the development of modern technology, people's way of life changed dramatically, with an increasing amount of time spent on the Internet, reading, watching TV and less time on sports and housework and other physical activity. These changes have led to the physical condition of the student declining. In 2010, the Ministry of Education made a Survey on National Student Physical Fitness and Health, the result of which indicates that the physical quality of college students (19-22 years old) showed a slow decline, and except the Sit and Reach achievement, other indicators such as endurance, power and strength have continued to decrease. Meanwhile, the obesity rate of the city and rural boys and girls aged from 7 to 22 are $13.33 \%, 5.64 \%$, $7.83 \%$ and $3.78 \%$, an increase of $1.94,0.63,2.76$ and 1.15 percentage points from those in 2005 ; the overweight detection rates were $14.81 \%, 9.92 \%$, $10.79 \%, 8.03 \%$, an increase of $1.56,1.20,2.59$ and 3.42 percentage points more than those in 2005 .

Social responsibility of contemporary college students not only contains a variety of social obligations they need to take, but also includes health awareness, responsibility, because only when one has in physical and psychological health can he be able to take the social responsibility. The essential function of sport is fitness and strength. Appropriate physical exercise not only can promote morphological and physiological function but also can improve their ability to adapt to the natural environment, reducing the risk of various diseases. Only a healthy body can help the students develop a healthy spirit. In physical education activities, lectures on nutrition, sports and health could serve to improve students' self-awareness of health so as to promote their exercise habits and lay the foundation of good health for their future work and life.

\section{AWARENESS OF LAW AND THE RULES SHOWS ONE'S SENSE OF RESPONSIBILITY}

As an old saying goes: in the management of state affairs, it is not the legislation that is difficult but the implementation of law; it is not listening to the words that is hard but obeying it. It is easy to legislate laws and policies and difficult to implement them; it is not hard to listen to the words but is difficult to follow them. In his view, the laws and regulations and other policies in Ming dynasty was enough, but the country was still chaotic in management. The problem is not lack of law, but 
that no one can seriously implement and comply with the law. Historical experience has proven that all prosperous dynasty benefit from a strict legal system and good policy and all the declining dynasties paid the cost of official corruption and abuse of power. In the great historical period of national revival, we need a more favorable legal environment, and more importantly, the citizens should have a sound awareness of the law.

Stadium is a projection of society, as legal and community awareness required by social life is also necessary here. In a variety of sports competitions, students must obey the court referee and respect the rules, which can effectively develop the spirit and awareness of the rules and fairness. This awareness can be generalized to their daily lives, so that students in social life can consciously study, follow and comply with laws and regulations. Such goodmannered citizens will certainly contribute more to the society.

\section{TEAM SPIRIT, AN IMPORTANT COMPONENT OF COLLEGE STUDENTS' SOCIAL RESPONSIBILITY}

Competition and cooperation are an important features of sports. In the competitive arena, when each player makes every effort to win the game, they need also cooperate with and support each other as a team in order to defeat opponents. In the 2014 World Cup, Germany eventually won the championship, with 18 goals in 7 games by eight players. Compared with the Argentina which boasted of their star of Messi, the German team has an advantage in their whole team. The goalkeeper Neuer told the media that "Our team is very united, and on and off the court all the players are striving for the same goal, which is why we can beat Brazil, Argentina and other teams, to become the world champion."

According to psychological research, sport can effectively enhance the people's social adaptation and resilience, and improve their mental control ability. Those who regularly participate in sports can form a good relationship with others easily. Team spirit of sports requires mutual support between the athletes, athletes and coaches, athletes and staff, in order to successfully achieve the objectives and tasks. Students who participate in various sports competitions can develop a good spirit of cooperation and teamwork, which have a very positive impact on their future work and life.

\section{COMPETITION AWARENESS IS AN ESSENTIAL PART OF SOCIAL RESPONSIBILITY}

With the rapid development of information science and technology, life science and technology and aerospace engineering, the inter-country competition is more becoming more intense. College students not only need to have a wealth of knowledge and skills, but also to have a tenacious spirit to adapt to social development. A "civil mind and barbarian physique" is the ideal combination. Fierce confrontation in sports competition is a good way for college students to develop hard-working and tenacious spirit. In their fight for the champion, they can fully experience that success is not easy and the value of failure, thus they could have a more positive attitude to look at and face life's difficulties and become more resilient. Besides, the fight with stress and frustration and a rich variety of experiences on the arena will also become a valuable asset in their life.

In summary, sports, as an integral part of college life, cannot only enhance physical fitness and health awareness, but also could help develop students' awareness of rules, teamwork and fighting spirit, thus effectively promoting college students' social responsibility. Therefore, universities and relevant education departments should pay full attention and take advantage of these features of sports, and actively carry out activities and deliver targeted ideological and moral education, so that the college students could become qualified builders and successors to realize national revival.

\section{ACKNOWLEDGEMENT}

This research was financially supported by the North China institute of science and technology teaching research Foundation.( HKJY201443)

\section{REFERENCES}

[1] Guo-qiang dong. Based on the concept of "moral education first" moral education in colleges and universities work method research, Journal of modern long-distance education

[2] Feng Xia. Contemporary college students social responsibility education and training to explore, Journal of academic BBS, 2009

[3] Xiao-wei li. The physical health condition of students happy optimal mixed - 2010 student physique health monitoring research results were announced, physical education, 2011

[4] Li Shudong, hong-hong zhou, zuo-qing sun. College students' social responsibility and the ideological and political education effectiveness analysis, Journal of Inner Mongolia education, 2012 